\title{
Analysis of the Competitiveness of Serbia in Relation to the Region Countries Established by the New Index of Competitiveness
}

\author{
Aleksandar Kuzmanovic \\ Financial Manager, City of Aleksinac, State Republic of Serbia
}

Copyright $(2017$ by authors, all rights reserved. Authors agree that this article remains permanently open access under the terms of the Creative Commons Attribution License 4.0 International License

\begin{abstract}
Competitiveness has become the dominant economic theme. Its character, in addition to the traditional supply needs to be more competitive or better than others, contributed to the world economic crisis through which passes all the economy, including the Serbian. The importance of competitiveness stems from the fact that it finds its use of all available resources. For each country, it is important to look at the quality of the use of available resources. Serbia since the beginning of the 2008 crisis, until now, achieved worsening levels of competitiveness. The research work highlights the basic directions of deterioration or improvement, competitive position during the crisis. The subject of the work is meaningful because the competitiveness of each country is based on the productivity of the use of all available resources. The level of competitiveness made by Serbia in $2016-90^{\text {th }}$ in the world, among 138 countries - is not satisfactory even though Serbia has significant potential for raising its competitiveness. This is especially confirmed by the fact that at the level of GDP, according to purchasing power parity, Serbia is on the $70^{\text {th }}$ place in the world. By the analysis of indicators of competitiveness and quality of business we have pointed out the competitive disadvantages of Serbia and we have defined the trajectory of how competitive advantage can be achieved. The analysis is based on a comparison of 2007 and 2016. In addition to the analysis of the competitive position of Serbia, a sample of countries in the region is also analysed to determine the position of Serbia in the region from the perspective of the level of competitiveness.
\end{abstract}

Keywords Competitiveness, a New Global Index of Competitiveness, Indicators of Competitiveness

\section{Introduction}

In terms of macroeconomic theory, the competitiveness would include the ability of an open economy that simultaneously achieves sustained full employment and sustainable level of current and overall balance of payments. This analysis on the structural competitiveness factors which influence the allocation of resources and the key aspects of economic efficiency (such as productivity, innovation, technical progress, knowledge and education, etc.) complicates the analysis and, after Krugman, denies the postulate of the theory of comparative advantage which in fact argues that the countries cannot compete with each other directly (as companies do) that in the world there is a place for everybody and that foreign trade is "a positive sum game" in which, under the factors in a given schedule, everybody wins.

This analysis aims to present Serbia's position towards the achieved level of competitiveness for 2016, according to the list of the World Economic Forum (WEF), compared with the countries in the region and lay the foundation for improving the position in the future. It is also pointed to factors that decisively influenced the changes that led to the current position of Serbia.

The aim of the New Global Competitiveness Index (New GCI) is to create a single, fully integrated index to replace the two indexes published in recent years. The New GCI will be based on a single model that is firmly grounded in the latest academic research while designed to extend research and yield practical insights for policy-makers. The New GCI will also create a stable method-logical platform for the years to come. The New GCI will concentrate on the determinants of the productivity level that a national economy can sustain, which is the ultimate driver of national prosperity. Data will continue to be drawn from a mix of public sources and the unique and proprietary annual Survey of many thousands of business executives from around the world. The majority of the individual indicators used in the previous indexes will be incorporated into the new index.

\section{The Methods That Were Applied in the Study}

Analytical-empirical research method was used when 
writing this work, which is supported by studying the adequate and varied literature, as well as opinions, statements and conclusions of the respective authors. We used a developmental type of research, namely development studies. Used opinions ascertainment, conclusions and literature do not belong to an identical period of time and are the result of years of research and work in this area.

During the theoretical and methodological research in the process of making this work it is used:

- Historical - descriptive method,

- Analytical methods,

- Comparative methods and

- Empirical methods.

Historical method and descriptive method explored the theoretical frameworks and mechanisms, competition and the effects in the Serbian economy, as well as the overall ambience and appeal of Serbian economy to foreign investment. Using empirical, analytical and comparative method analysed and compared the competitiveness of Serbia and countries in the region (Montenegro, BIH, Croatia etc.).

All of the above indicators are observed in the case of Serbia, and then compared with the other countries that have gone the way of the transition and in regional countries.

GCI (Global Competitiveness Index), a composite index, is formed as a weighted average value of each of these pillars. Otherwise, each of these pillars is by itself a composite index that is formed as a weighted average of sub-indicators whose values are derived from two types of sources - primary and secondary.

Primary data are obtained on the basis of standardized surveys that are conducted every year in the countries covered by the corresponding representatives of the highest managerial level ("top managers") enterprises which form a representative sample. Number of companies that are included in the sample varies from country to country and depends primarily on its size. The sample consists of small, medium and large companies. Shares of enterprises by size in the sample are precisely defined guidelines WEF. It is important to mention that each year half of the sample is formed by the companies that were in the sample of the previous year, while the other half is chosen randomly from a defined sampling frame.

For the calculation of competitiveness indicators such as the level of taxes, inflation, budget deficit; the number of telephone lines; the number of procedures to start an entrepreneurial activity and the like; and the data from internationally comparable database (e.g. the base of the IMF, the World Bank, the International Trade Organization, the United Nations and others). These data are called "hard data" (hard data). When calculating the indicator for the current year are mainly used secondary data from the previous year, due to the fact that at the time of preparation of the report on the competitiveness of the base for the current year for this type of data generally not available. Thus, in preparing the report for the year 2016 are used secondary data from 2015.
In this regard, the representative of the current competitiveness of the data obtained from the survey.

All data, whether it is a primary or secondary, standardize on a scale of 1 to 7 ( 1 - the worst score 7 - best estimate), which is the range of possible values for all indicators, the pillars of the competitiveness and even the global index competitiveness. As far as most of the survey questions is not necessary to normalize, because it uses a balanced Likert scale with seven divisions. Participation in the survey data, the calculation GCI amounts to about $56 \%$, while the share of secondary data is approximately $44 \%$.

The significance of the poles within the group have the particular country depends on its level of development. For the grouping of countries according to their level of development is used relatively accurate and simple criterion is based on the realized level of GDP per capita, denominated in US dollars. The division was based on three primary and two transitional phases of economic development. Depending on the stage in which the country finds itself will depend on the value of the weights that are assigned to groups of pillars that form the value of the Global Competitiveness Index.

Serbia is among the countries according to the value of GDP per capita at the middle level of development, which is key driver of competitiveness as the columns of the group "factors to increase efficiency." In this regard, when calculating the composite value GCI, basic requirements were $40 \%$, efficiency enhancers with $50 \%$ and innovation and sophistication factors participate with $10 \%$. Accordingly, the value of the pillars of the group "factors to increase efficiency" has proportionately the greatest influence on the formation of the total value of the GCI when Serbia is concerned.

\section{New Global Competitiveness Index in Serbia and Region}

The competitiveness of an economy is measured through a global index of competitiveness, taking into account the 12 most important dimensions of an economy so that the national economy is considered from the aspect of development of the following twelve pillars. ${ }^{1}$

The twelve pillars of competitiveness are grouped into three separate entities, which are key to the different ways of managing the economy, such as: the basic factors of the economy, effectiveness of keeping the economy and innovative factors of the economy ${ }^{2}$.

1 The Global Competitivnes Report 2008-2009, (C) 2008 World Economick Forum

2 Global Competitiveness Report 2015-2016 
Basic requirements:

1. Institutions

2. Infrastructure

3. Macroeconomic environment

4. Health and primary education

\section{Improving efficiency:}

5. Higher education and training

5. The effectiveness of the protection of goods

6. Labor market efficiency

7. The financial market sophistication

8. Technological competence

9. Labor markets size

Effectiveness

of keeping the

\section{Innovation and sophistication:} 11. Business sophistication 10. Innovation

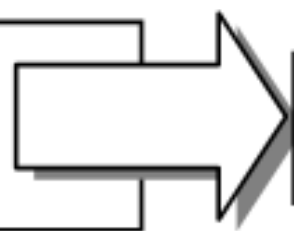

\section{Innovative factors \\ of the economy}

Table 1. The Global Competitiveness Index (2007-2016).

\begin{tabular}{|l|c|c|c|c|c|c|c|c|}
\hline & ALB & BIH & CRO & MCD & MNE & ROM & SRB & SLO \\
\hline $\mathbf{2 0 0 7}$ & 3,48 & 3,55 & 4,20 & 3,73 & 3,91 & 3,97 & 3,78 & 4,48 \\
\hline $\mathbf{2 0 0 8}$ & 3,55 & 3,56 & 4,22 & 3,87 & 4,11 & 4,10 & 3,90 & 4,50 \\
\hline $\mathbf{2 0 0 9}$ & 3,72 & 3,53 & 4,03 & 3,95 & 4,16 & 4,11 & 3,77 & 4,55 \\
\hline $\mathbf{2 0 1 0}$ & 3,94 & 3,70 & 4,04 & 4,02 & 4,36 & 4,16 & 3,84 & 4,42 \\
\hline $\mathbf{2 0 1 1}$ & 4,06 & 3,83 & 4,08 & 4,05 & 4,27 & 4,08 & 3,88 & 4,30 \\
\hline $\mathbf{2 0 1 2}$ & 3,91 & 3,93 & 4,04 & 4,04 & 4,14 & 4,07 & 3,87 & 4,34 \\
\hline $\mathbf{2 0 1 3}$ & 3,85 & 4,02 & 4,13 & 4,14 & 4,20 & 4,13 & 3,77 & 4,25 \\
\hline $\mathbf{2 0 1 4}$ & 3,84 & $/$ & 4.13 & 4.26 & 4.23 & 4.30 & 3.90 & 4.22 \\
\hline $\mathbf{2 0 1 5}$ & 3,93 & 3,71 & 4,07 & 4,25 & 4,20 & 4,32 & 3,89 & 4,28 \\
\hline $\mathbf{2 0 1 6}$ & 4,06 & 3,80 & 4,15 & 4,23 & 4,05 & 4,30 & 3,97 & 4,39 \\
\hline
\end{tabular}

Source: $\operatorname{WEF}(2007,2008,2009,2010,2011,2012,2013,2014,2015,2016)$ 
Established by the New Index of Competitiveness

Table 2. Rank countries according to the Global Competitiveness Index (2007-2016).

\begin{tabular}{|l|c|c|c|c|c|c|c|c|}
\hline & ALB & BIH & CRO & MCD & MNE & ROM & SRB & SLO \\
\hline $\mathbf{2 0 0 7}$ & 109 & 106 & 57 & 94 & 82 & 74 & 91 & 39 \\
\hline $\mathbf{2 0 0 8}$ & 108 & 107 & 61 & 89 & 65 & 68 & 85 & 42 \\
\hline $\mathbf{2 0 0 9}$ & 96 & 109 & 72 & 84 & 62 & 64 & 93 & 37 \\
\hline $\mathbf{2 0 1 0}$ & 88 & 102 & 77 & 79 & 49 & 67 & 96 & 45 \\
\hline $\mathbf{2 0 1 1}$ & 78 & 100 & 76 & 79 & 60 & 77 & 95 & 57 \\
\hline $\mathbf{2 0 1 2}$ & 89 & 88 & 81 & 80 & 72 & 78 & 95 & 56 \\
\hline $\mathbf{2 0 1 3}$ & 95 & 87 & 75 & 73 & 67 & 76 & 101 & 62 \\
\hline $\mathbf{2 0 1 4}$ & 97 & $/$ & 77 & 63 & 67 & 59 & 94 & 70 \\
\hline $\mathbf{2 0 1 5}$ & 93 & 111 & 77 & 60 & 70 & 53 & 94 & 59 \\
\hline $\mathbf{2 0 1 6}$ & 80 & 107 & 74 & 68 & 82 & 62 & 90 & 56 \\
\hline
\end{tabular}

Source: WEF (2007, 2008, 2009, 2010, 2011, 2012, 2013, 2014, 2015, 2016)

According to the World Economic Forum for 2016, Serbia is ranked 90th position in the ranking, which includes 138 countries to the recorded value of the Global Competitiveness Index (GCI) of 3.97. In doing so, it should be borne in mind that the theoretical value of the GCI is in the range of 1 to 7 . In comparison to the previous year value GCI Serbia increased by 0.08 as when we take into account the value of the index for other countries resulted in increased four cities (Serbia in the past two years ranked 94th on the list).

Compared with the previous report when the Serbian minimum value decreased by $0.01 \mathrm{GCI}$ and thus maintained the same position as two years ago, it can now be concluded slight improvement in almost all the pillars of competitiveness that WEF through this report follows. Changes in the value of individual pillars of which are obtained after weighting GCI for Serbia, the average stood at around $3.9 \%$ compared to the value of the previous year. Small changes can GCI value resulted in significant shifts in the rankings especially in the part of the list in which Serbia is due to the fact that the differences between neighboring countries, often at the level of GCI value of 0.01 or less. As examples of larger displacement of the countries in our region stand out Albania and Montenegro that are in relation to the previous year, on average, had a change of values by columns from $4.17 \%$ to $4.61 \%$, which has led to changes in their ranking of 13 or 12 positions on the list.

Tables 1 and 2 represent the data in the GCI and rank Serbia and the countries in its neighborhood for the period from 2007 to 2016. Tables included 8 countries: Albania, Bosnia and Herzegovina, Croatia, Macedonia, Montenegro, Romania, Serbia and Slovenia.

According to the value of the Global Competitiveness Index in 2016, Serbia is the only ranked better than Bosnia and Herzegovina, which occupies the 107th position in the ranking WFE. Among other neighboring countries of Albania, which last year was one place better ranked than Serbia (ranked 93 position) according to the latest report recorded a growth value GCI 0.13 points and thus improved its position by 13 places. Of the remaining countries analyzed, three improved GCI value compared to the previous year and thus its position (Croatia and Slovenia), while the remaining countries recorded a decline (Macedonia, Montenegro and Romania), which is most pronounced in the case of Montenegro, which after last year's 70, now ranked 82 on the list.

Based on the data from Table 2, it shows the movements of GCI for Serbia and the average of the observed countries, from which it can be concluded that although there is a trend of growth in the case of Serbia is present much greater instability, reflected in significant fluctuations in the short term than the average observed countries. After the outbreak of the global financial crisis in 2009, it was followed by the deterioration of the competitive position of Serbia, which was considerably higher than in other countries in the region. After a slow recovery in 2013 was followed by re-pad on the list who was one of the largest in the observed group of countries. According to the latest report, half of the countries in the region recorded a decline in the value of GCI this year, as the growth in Serbia has made impact to reduce Serbia's lagging behind the average for the region. This lag far now amounts to 0,181 points, a difference of about 15 places in the rankings.

The Table 3 below shows the change in value of GCI pylon for the period 2014-2016 years, in which we can clearly determine which poles are responsible for the change in value GCI between last years.

Solid progress has been made and in the pillar of development of the financial market mainly due to slightly better marks than last year, which gave top managers on the ease of obtaining credit and the possibilities of finding capital to finance entrepreneurial projects. The progress achieved in these two indicators was sufficient to compensate for weaker assessment obtained to the question about the price of lending to businesses. As with the previous steps, the progress made in the field of development of financial markets was only so much that Serbia is placed 110 th in the ranking (Table 3 ).

This increase of the GCI for Serbia were affected and more noticeable improvement in the pillars of higher 
education and training, labor market efficiency, as well as stairs Health and primary education. In the stairs Higher education and training progress is owed to higher values of responses that are lead managers on the issue of whether the quality of the education system, the quality of education in mathematics and science, as well as the availability of various specialization courses for workers. Also, a slightly higher rate of enrollment in tertiary education level compared to last year has further increased the value of this column.

Table 3. Value GCI by columns of competitiveness

\begin{tabular}{|c|c|c|c|c|}
\hline & Column of Competitiveness & $\mathbf{2 0 1 4}$ & $\mathbf{2 0 1 5}$ & $\mathbf{2 0 1 6}$ \\
\hline 1. & Institutions & 3,21 & 3,24 & 3,31 \\
\hline 2. & Infrastructure & 3,93 & 3,87 & 3,94 \\
\hline 3. & Macroeconomic environment & 3,51 & 3,61 & 4,12 \\
\hline 4. & Health and primary education & 5,76 & 5,87 & 5,97 \\
\hline 5. & Higher education and training & 4,25 & 4,27 & 4,40 \\
\hline 6. & The effectiveness of the protection & 3,78 & 3,74 & 3,78 \\
\hline 7. & of goods & 3,73 & 3,72 & 3,84 \\
\hline 8. & The financial market sophistication & 3,50 & 3,23 & 3,41 \\
\hline 9. & Technological competence & 3,45 & 4,47 & 4,05 \\
\hline 10. & Labor markets size & 3,68 & 3,70 & 3,63 \\
\hline 11. & Business sophistication & 3,21 & 3,14 & 3,15 \\
\hline 12. & Innovation & 2,89 & 2,90 & 2,97 \\
\hline
\end{tabular}

Inside the pillars of labor market efficiency have been obtained better grades in matters related to the quality of relations between employers and employees, ease of hiring and firing workers, the effects of tax incentives for job search, links between wages and productivity and hiring professional management in companies. Yet despite the progress Serbia has made towards the value of the pillars of the 106th position on this year's list which testifies to a very bad attitude of top managers over the way in which the labor market is regulated in Serbia.

One of the pillars according to which Serbia is much better placed in relation to other factors of competitiveness Health and primary education, and this year recorded a growth. The indicators in the pillar related to health care have not been significantly changed or are the indicators that follow primary education recorded an increase compared to last year. A better estimate is given by managers to the question about the quality of basic education in the country which is combined with a slightly higher rate of enrollment in primary schools contributed to the overall value of the steps increases compared to last year.

Positive changes can be expected with gross national savings and credit rating in the next report. The only negative trend (at least the next three years), which is quite certain is related to the assessment of public debt. According to the plan of fiscal consolidation that is applied in Serbia, the growth of public debt will be stopped early in 2017 on the condition that all the planned measures fully implemented no major shocks that could prevent the achievement of this goal.

Porter is (Porter, Michael E, 2008) studying the success of national economies globally developed a model of national competitive advantage. In the model called "national diamond" competitiveness of the economy, i.e. the observed industry is explained by the interaction of four essential determinants:

1) Conditions related to the factors of production (labor, capital, land, natural resources and infrastructure).

2) Conditions relating to demand on domestic market,

3) Ancillary industry (internationally competitive),

4) Company strategy, structure and quality ${ }^{3}$.

The operations of economic entities in the Republic of Serbia has been affected by numerous factors external and internal nature, whose negative effect greatly complicates economic activity participants in the domestic market. One consequence of these market conditions is certainly a big illiquidity company, which is becoming one of the main characteristics of the average Serbian companies.

Figure 1 shows the factors that companies are listed in survey as the most problematic for doing business in the 2016. The competitiveness of each country is determined by the productivity of companies that do business there. Therefore, it is important to analyze the opinion of employees on which factors most affect the decrease in productivity Business. Results show that in the opinion of employees in Serbia, the biggest problems affecting the decrease in productivity: tax rates $(11,8 \%)$, inefficient government bureaucracy $(10.6 \%)$, political instability $(9 \%)$, and access to financing $(9 \%)^{4}$.

Below we will see what are the benefits contributed to the increase of foreign direct investments and increase the export potential of Serbia.

- During 2016, the net inflow of foreign direct investment amounted to 1.8 billion euros, slightly more than in the same period last year, focused mainly in export-oriented sectors.

- Correcting the business environment was confirmed on the list Doing Business of World Bank (47th place). Serbia is in the group of 10 countries that most improved their business environment.

- Before the crisis, the largest part of foreign direct investment was directed to the non-tradable sector, such as finance, construction and real estate activities. After the outbreak of the crisis, especially during the last four years, the structure of foreign direct investment is corrected by the fact that the investment is directed to the tradable sectors.

As a result of this accelerated growth is expected on the basis of macroeconomic stability, improving the business environment, increased government investment, the effects of the relaxation of monetary policy in the previous period, enforcement structural reforms and the recovery of external and domestic demand.

3 Porter, M: The Competitive Advantage of Nations. In: On Competition-Updated and Expanded Edition. MA. Harvard Business School Press, Boston, 171-211. (2008)

4 Klaus, Xavier (2011: 294) 
Most problematic factors for doing business soure:-Word teconomic Forum. Execurtive opinion Surey 2016

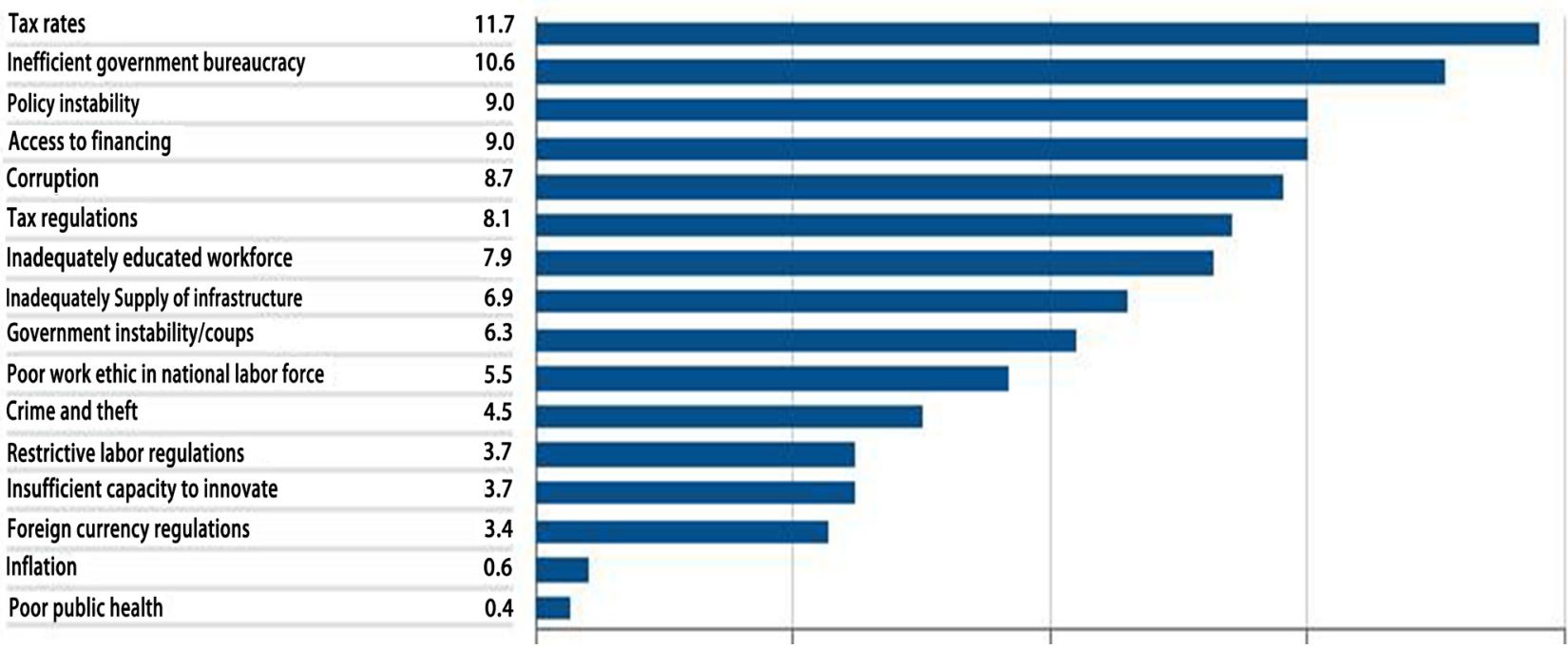

Figure 1. The most problematic factors for doing business in Serbia 2015-2016

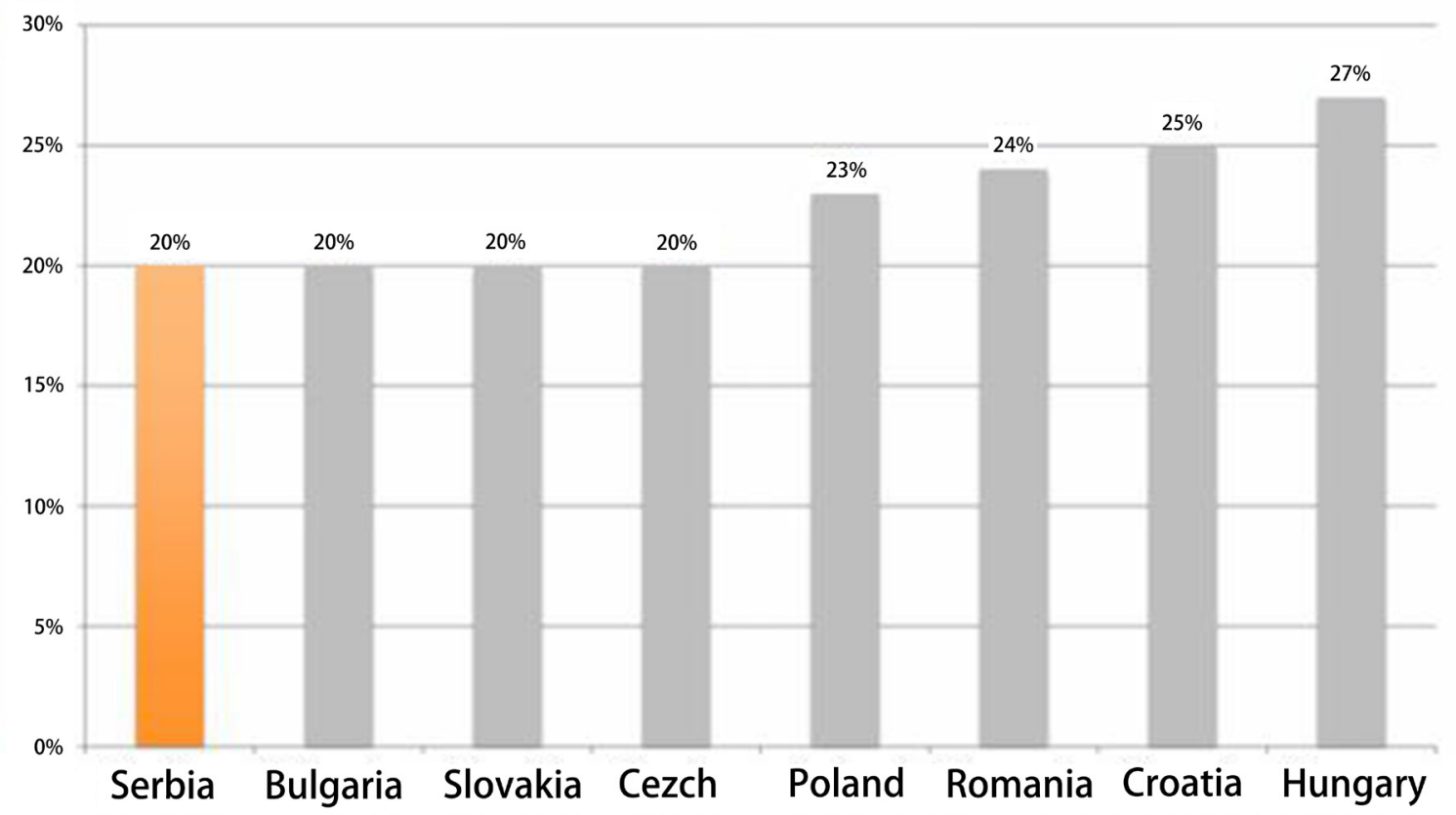

Figure 2. VAT rate in region 


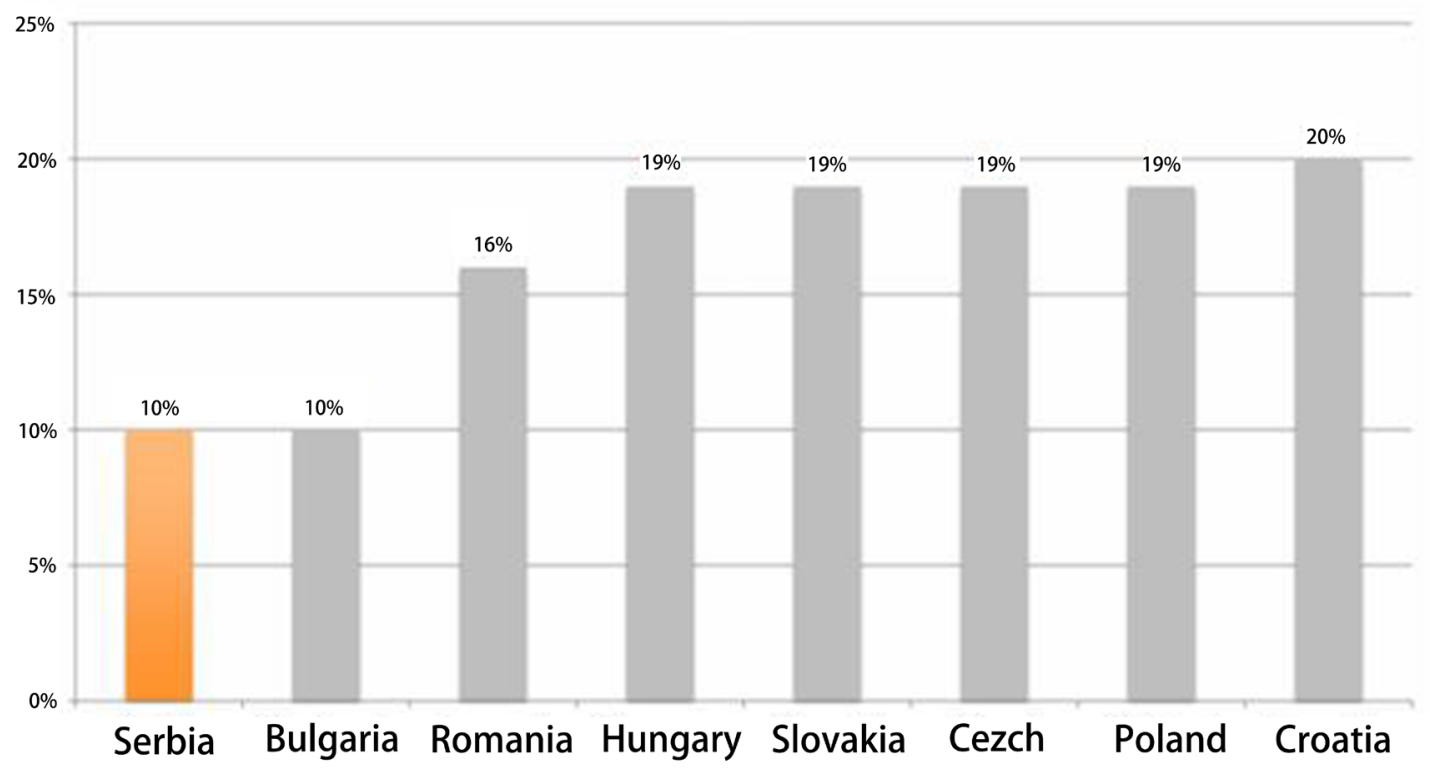

Figure 3. The rate of corporate income tax in region

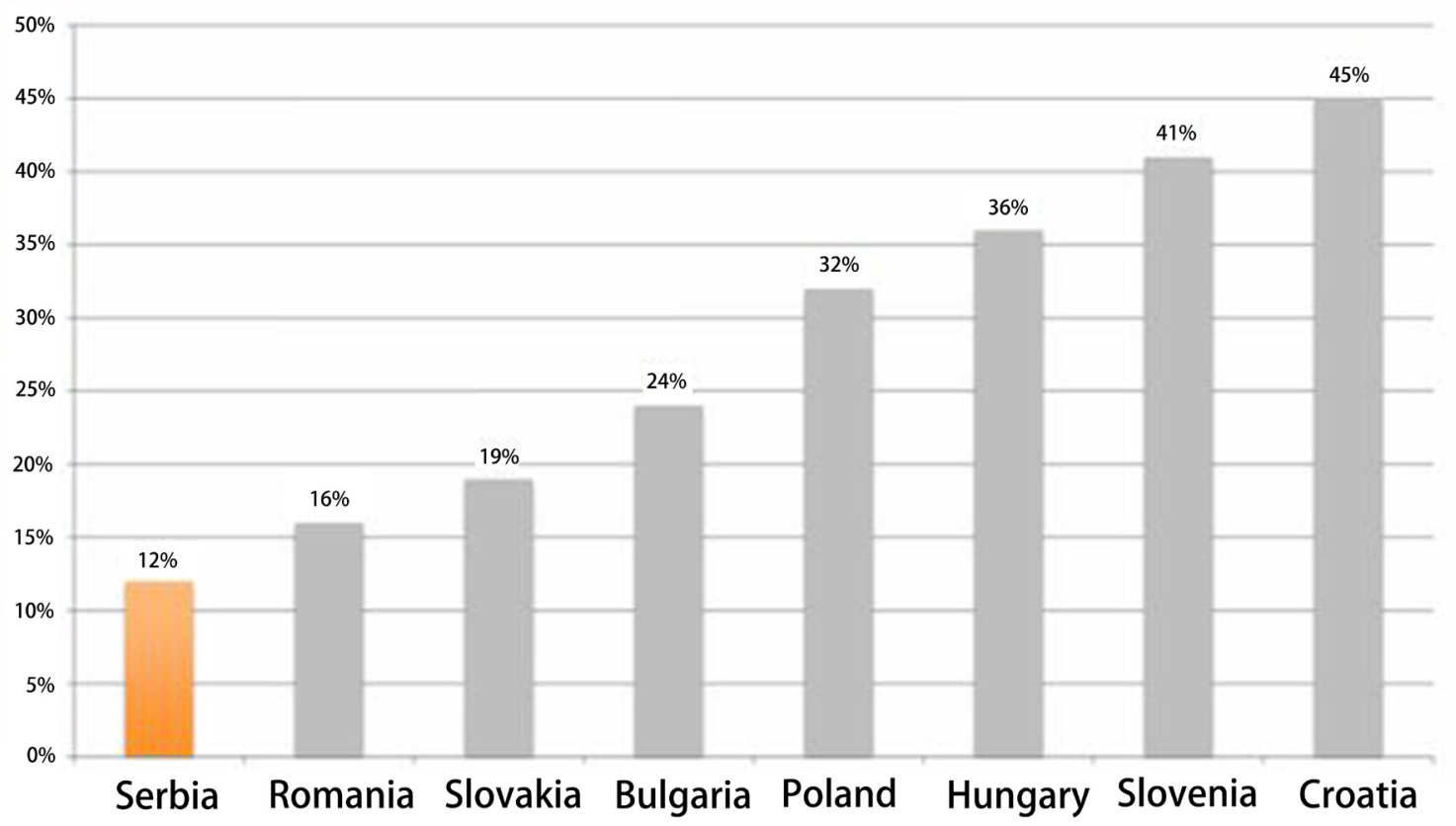

Figure 4. Tax rate on earnings in region

\section{Conclusions and Discussion}

Competitiveness is not only one of the "strings" of business and enterprise development, and the economy. Today competitiveness is the struggle to enter and survive in the market operations. Economic policy must develop competitive advantages of Serbian economy, not just comparative advantages. Creating favourable conditions for foreign investments exceeds the standard macroeconomic assumptions. Necessary economic policy without interference of bureaucratic authority, and certainly without administrative delays in registration, issuing permits, employment, exports, providing the necessary legal protection and others in addition to the required efficiency of the banking system, i.e. the financial system.

Every country which seeks greater prosperities must objectively examine their strengths and weaknesses and that hard work is maintained and if possible increases their competitiveness.

Analysis of the building components GCI showed that Serbia stands very bad in terms of competitive advantage compared to other countries in the region. However, the factors that affect the improvement of competitiveness are increasing and there are indications that in the coming years, 
the competitiveness of Serbia will be at a higher level.

The upward trend of certain pillars of competitiveness stems primarily from a stable political and economic situation in the country. The Serbian government has taken appropriate measures to prevent the further deepening of the crisis in Serbia. The Serbian government has based the development of economic competitiveness and stability in the 3 main pillars, increase investment, increase exports and increase public spending.

- Exports of goods had a value of 7,691 billion euros, an increase of 8.9 percent compared with the same period of the previous year. Import of goods had a value of 9.90 billion euros, an increase of 5.2 percent compared to the same period last year. The deficit amounted to 2.21 billion euros, a decrease of six percent compared to the same period of the previous year. The coverage of imports by exports was 77.7 percent higher than in the same period of the previous year, when it stood at 75 percent.

- In 2016. Serbia had about 1,8 billion of foreign direct investment.

- The unemployment rate is about $13.8 \%$, which is lower about $2 \%$ compared to the same period last year.

- The inflation rate in 2016.was $1,6 \%$.

- GDP has increased by about 2,7\%. Based on GDP is possible to locate areas that are critical to achieving economic growth and improving competitiveness. According to preliminary data, GDP in 2016 rose by $2.7 \%$, driven by agriculture, industry, construction and services of private sector. On the expenditure side, GDP growth was predominantly driven by investment, a positive contribution to growth originated from net exports and final consumption. In the future it is expected gradual acceleration of growth, which will reach 3\% this year and $3.5 \%$ in 2018 , while maintaining a favorable composition of growth.

- In 2016 there was an increase wages in public sector, and pensions by $1,5 \%$.

- In 2016 the Government of Serbia given from the budget over then 100 million in subsidies. These incentives receive domestic and foreign companies in the amount of 4,000 to 10,000 per new job created, and depending on the number of new workers.

All this has led to the fact that Serbia has been a reduction in the budget deficit for the first time in many years ago and Serbia is on a good way to improve the economic stability of the country.

Pursuant to the results of Figure 1, Serbia needs to prepare complex development policy and clearly define the competitive advantages of its economy in the future.

Serbia should see its development only in those segments where it can be competitive in relation to countries in the region.

1. Agriculture and food industry

Serbia should use the Ukrainian crisis and the EU sanctions against Russia, and increase the export of food products to the Russian Federation. The Government and the line ministry should enable agricultural producers grant credits for irrigation systems and planting new fruit and vegetables. The banking sector should provide cheaper, subsidized loans for the purchase of new machinery and equipment investment in the food industry.

\section{Natural resources and energy}

3. Support and Development of Small and Medium Enterprises,

4. The project "Belgrade on water" can contribute to a significant improvement in the competitive position of Serbia

5. Investment in education, young talents, support research projects, investment in brands, research projects, etc.

All this would not have success without serious reform of the education system in Serbia. The essence of the changes in secondary and higher professional education should be striving to establish a flexible system of professional education that would respond to the changing requirements of the labor market and facilitate the acquisition of knowledge and values for better and faster professional development and career. It is especially important to develop partnerships of universities with industry and international institutions.

The relationship between knowledge and entrepreneurship is essential to determine the competitiveness of an economy. Increased economic complexity is necessary for a society to be able to hold and use a larger amount of productive knowledge, and we can measure it from the mix of products that countries are able to make. The complexity of an economy is related to the multiplicity of useful knowledge embedded in it. For a complex society to exist, and to sustain itself, people who know about design, marketing, finance, technology, human resource management, operations and trade law must be able to interact and combine their knowledge to make products.

Competitiveness of Serbia - ADVANTAGES: Foreign trade agreement with Russia, the EU, EFTA, with Turkey, USA, China and other major countries that are significant consumers of food in the world, Excellent geographical location, significantly lower than the countries in the region, Cheap manpower, $0 \%$ tariff rate for imports of goods intended for export, a favorable tax environment.

Creating recognition of Serbia as a land of investment opportunities, market economy, open borders, is ready to be competitively integrated into the European mainstream and represents the national interest of the Republic of Serbia. On these grounds, it can justify the essential commitment of the Serbian Chamber as the leading association of Serbian businessmen. Working actively to improve the economic development of the country, increasing exports and foreign direct investment, strengthening the competitiveness of Serbian economy and developing entrepreneurship, and 
promoting economic area of Serbia as an investment destination respectable, are the strategic goals the Chamber of Commerce of Serbia and the economic diplomacy of the Republic of Serbia.

\section{REFERENCES}

[1] Annoni, P., K. Kozovska: "EU Regional Competitiveness Index", JRC Scientific and Technical Report 23306 EN

[2] M. Arsic, Pavle P., (2009), "Challenges of macroeconomic policy: short and medium term," Economic Policy of Serbia in 2010, Faculty of Economics, Belgrade
[3] J. Bajec, Competitiveness of Serbia, 2011 Jefferson Institute.

[4] Čučuk A., "Financial Globalization" Scientific Book, Belgrade, 2008

[5] Devetaković S., Rikalović G., Jovanović-Gavrilović B., 2006. The national economy, CID Faculty of Economics, Belgrade.

[6] Porter, M: The Competitive Advantage of Nations. In: On Competition-Updated and Expanded Edition. MA. Harvard Business School Press, Boston, 171-211. (2008)

[7] Klaus, S., Xavier S., (2011) Global Competitiveness report 2010- 2011, World Economic Forum. Esser, K. Hillebrand, W. Messner, D., Meyer-Stamer, J. (1995) Systemic Competitiveness. New Governance Patterns for Industrial Development. London: Frank Cass (GDI Book Series, No.5). 